\section{Postbaccalaureate PharmD Programs for Canadian Pharmacists: Options and Considerations}

Substantial changes are occurring in the education of Canadian pharmacists. Over the past decade, there has been a transition from the Bachelor of Science in Pharmacy (BScPharm) to the entry-level Doctor of Pharmacy (ELPD). ${ }^{1}$ With some universities already graduating ELPD students, practising pharmacists may be reflecting on program options to obtain a postbaccalaureate PharmD or ELPD equivalent.

\section{Program Options for Postbaccalaureate PharmD}

Several programs are available to Canadian pharmacists seeking a postbaccalaureate PharmD; however, the specifics of the programs differ widely (Table 1)..$^{2-6}$ Until recently in Canada, traditional postbaccalaureate $\mathrm{PharmD}$ programs were available from the University of British Columbia ${ }^{2}$ and the University of Toronto. ${ }^{6}$ However, with the University of Toronto suspending its full-time program, the University of British Columbia is the only Canadian institution enrolling full-time postbaccalaureate PharmD students in 2014. For those interested in part-time studies, nontraditional postbaccalaureate PharmD distance programs remain an option. ${ }^{3,4}$ Additionally, the University of British Columbia, ${ }^{2}$ University of Toronto, ${ }^{6}$ and University of Waterloo ${ }^{5}$ anticipate enrolment in a postbaccalaureate PharmD "bridging" program in the coming months. These bridging programs will develop the knowledge and skills of baccalaureate-trained pharmacists comparable to ELPD graduates. Available programs continue to evolve.

\section{Considerations for Continuing beyond a Baccalaureate Degree in Pharmacy}

Within the profession, opinions differ regarding the transition to the ELPD. Some pharmacists express concern over employment stability, while others are confident in their education and work experience. Certainly the ELPD program does not lessen the value of a baccalaureate degree or years of experiential learning. Nevertheless, some practitioners continue to seek further education.

As a pharmacist, why return to life as a student? According to recent graduates, the most common reason for completing a postbaccalaureate PharmD program is to remain competitive within the profession. ${ }^{7}$ There are numerous programs, in addition to the PharmD, available to pharmacists, including pharmacy residencies, doctoral and master's programs, and MBA (master of business administration) programs, that potentially offer a competitive edge. A specific program should be selected based on alignment of the program's objectives with the individual's career goals.

Although job satisfaction is multifactorial, improvement in this area is a common reason for seeking a postbaccalaureate PharmD. ${ }^{7}$ These educational programs increase satisfaction by allowing knowledge development that will improve patient care and advance clinical practice, as well as leadership and research skills. Pharmacists interested in management, research, or education may also wish to pursue a postbaccalaureate PharmD, as graduates from these programs have been found to spend more time working within these areas relative to pharmacists with a baccalaureate degree or an ELPD. ${ }^{8}$ Postbaccalaureate PharmD graduates obtain the skills and knowledge required to achieve and succeed in various desirable job opportunities.

Even the most motivated student should consider the difficult balance of pursuing career advancement with achieving personal goals. Pharmacists completing a postbaccalaureate PharmD program will experience a range of delays in achieving their personal goals. Postbaccalaureate PharmD programs may require relocating or being away from home for extended periods of time. Additionally, staggering tuition fees are common among the programs available to Canadians (Table 1). Personal sacrifices should not be overlooked.

Although several options currently exist for Canadian pharmacists seeking a postbaccalaureate program, the programs vary greatly in content, duration, and cost. Therefore, each individual should select the program that will best support his or her career goals. Potential postbaccalaureate PharmD students would be wise to explore each program's benefits and drawbacks in relation to both career and personal endeavours. 
Table 1. Postbaccalaureate PharmD Programs Available to Canadian Pharmacists

\begin{tabular}{|c|c|c|c|c|c|}
\hline \multirow[b]{2}{*}{$\begin{array}{l}\text { Type of PharmD } \\
\text { Program and } \\
\text { Institution }\end{array}$} & \multirow[b]{2}{*}{$\begin{array}{l}\text { Type of } \\
\text { Study }\end{array}$} & \multicolumn{2}{|c|}{ Duration } & \multirow[b]{2}{*}{$\begin{array}{l}\text { Total Cost } \\
\text { (Can\$)* }\end{array}$} & \multirow[b]{2}{*}{ Class Size } \\
\hline & & Total & $\begin{array}{c}\text { Experiential } \\
\text { Training }\end{array}$ & & \\
\hline \multicolumn{6}{|l|}{ Traditional } \\
\hline $\begin{array}{l}\text { University of British } \\
\text { Columbia }^{2}\end{array}$ & Full-time & $20 \mathrm{mo}$ & $12 \mathrm{mo}$ & 44000 & $\begin{array}{l}\text { Small (e.g., } 8 \\
\text { graduates in 2013) }\end{array}$ \\
\hline \multicolumn{6}{|l|}{ Nontraditional } \\
\hline University of Colorado ${ }^{3}$ & Part-time & $3 \mathrm{yr}$ (minimum) & $30 w k+$ & 42880 to 58910 & Variable \\
\hline University of Florida 4 & Part-time & $3 \mathrm{yr}$ (minimum) & 4 wk (minimum) & 45360 to 63720 & Variable \\
\hline \multicolumn{6}{|l|}{ ELPD Bridging Program } \\
\hline University of British Columbia² & Part-time & 3 to $5 \mathrm{yr}$ & 6 mot & $\begin{array}{l}\text { Not yet available; } \\
\text { anticipated } \\
\text { enrolment } \\
\text { January } 2016\end{array}$ & 20 to 30 \\
\hline University of Waterloo 5 & Part-time & $8 \mathrm{mo}$ to $3 \mathrm{yr}$ & \multicolumn{3}{|c|}{$\begin{array}{l}\text { Additional information to be released mid-2014; anticipated } \\
\text { enrolment in } 2015 \text { for University of Waterloo BScPharm } \\
\text { graduates (i.e., those who completed the program within } \\
\text { past } 3 \text { yr) }\end{array}$} \\
\hline University of Toronto ${ }^{6}$ & $\begin{array}{l}\text { mation re } \\
\text { ipated en }\end{array}$ & $\begin{array}{l}\text { ing admission cri } \\
\text { ent in } 2014\end{array}$ & ia, tuition cost, an & program duration & not yet available; \\
\hline
\end{tabular}

$\mathrm{N}==\mathrm{ELPD}=$ entry-level PharmD.

* US dollars were converted to Canadian dollars using a conversion rate of \$1.08 (Bank of Canada, July 17, 2014).

tFor students with prior practice experience, the University of Colorado and the University of British Columbia offer the option to challenge experiential training for credit.

\section{References}

1. Zubin A, Ensom MHH. Education of pharmacists in Canada. Am J Pharm Educ. 2008;72(6):128.

2. Graduate doctor of pharmacy program. Vancouver (BC): University of British Columbia, Faculty of Pharmaceutical Sciences; [cited 2014 Jan 16]. Available from: www.pharmacy.ubc.ca/programs/degree-programs/PharmD

3. iPharmDô North American-trained PharmD program. Denver (CO): University of Colorado, Skaggs School of Pharmacy and Pharmaceutical Sciences; 2013 [cited 2014 Jan 16]. Available from: www.ucdenver.edu/ academics/colleges/pharmacy/Admissions/iPharmD/NTPD/Pages/NTPD.aspx

4. Pharm.D. working professional doctor of pharmacy distance learning. Gainesville (FL): University of Florida, College of Pharmacy; [cited 2014 Jan 16]. Available from: http://pharmd.distancelearning.ufl.edu/pharm-d-program/

5. PharmD Bridging Program frequently asked questions. Waterloo (ON): University of Waterloo, School of Pharmacy; 2014 [cited 2014 Jan 21]. Available from: https:/uwaterloo.ca/pharmacy/distance-education-continuingprofessional-development/pharmd-bridging-program-frequently-askedquestions- 0

6. Post-baccalaureate doctor of pharmacy. Toronto (ON): University of Toronto, Leslie Dan Faculty of Pharmacy; [cited 2014 Jan 16]. Available from: www.pharmacy.utoronto.ca/post-bac-pharmd
7. Fjortoft M, Weigand L, Lee M. Effect of the nontraditional PharmD degree on practice patterns based on a survey of graduates from six programs. Am J Pharm Educ. 1999;63(3):305-9.

8. Kreling DH, Doucette WR, Change EH, Gaither CA, Mott DA, Schommer JC. Practice characteristics of Bachelor of Science and Doctor of Pharmacy degreed pharmacists based on the 2009 National Workforce Survey. Am J Pharm Educ. 2010;74(9):Article 159.

Amy Smith, BSP, ACPR

Candidate, Post-Baccalaureate Doctor of Pharmacy (PharmD)

Leslie Dan Faculty of Pharmacy

University of Toronto

Toronto, Ontario

Competing interests: None declared.

\section{Acknowledgements}

The author thanks Zubin Austin, PhD, Leslie Dan Faculty of Pharmacy, University of Toronto, for advice and presubmission review of the manuscript . 